The Hudson Primer 
This page intentionally left blank 


\title{
The Hudson Primer
}

The Ecology of an Iconic River

\author{
David L. Strayer
}

甲

UNIVERSITY OF CALIFORNIA PRESS

Berkeley Los Angeles London 
University of California Press, one of the most distinguished university presses in the United States, enriches lives around the world by advancing scholarship in the humanities, social sciences, and natural sciences. Its activities are supported by the UC Press Foundation and by philanthropic contributions from individuals and institutions. For more information, visit www.ucpress.edu.

University of California Press

Berkeley and Los Angeles, California

University of California Press, Ltd.

London, England

(C) 2012 by The Regents of the University of California

Library of Congress Cataloging-in-Publication Data

Strayer, David Lowell.

The Hudson primer : the ecology of an iconic river / David L. Strayer. p. $\mathrm{cm}$.

Includes bibliographical references and index.

ISBN 978-0-520-26960-6 (cloth, alk. paper) - ISBN 978-0-520-2696I-3 (pbk., alk. paper)

I. Hudson River (N.Y. and N.J.) - Environmental conditions. 2. New York (State)-Environmental conditions. 3. Estuarine health-Hudson River (N.Y. and N.J.) 4. Stream ecology-Hudson River (N.Y. and N.J.) 5. Natural historyHudson River (N.Y. and N.J.) 6. Human ecology-Hudson River (N.Y. and N.J.) 7. Nature-Effect of human beings on-Hudson River (N.Y. and N.J.) 8. Environmental protection-Hudson River (N.Y. and N.J.) 9. Water-PollutionHudson River (N.Y. and N.J.) $\quad$ Io. Restoration ecology-Hudson River (N.Y. and N.J.) I. Title.

GEI55.N7S73 2012

$55 \mathrm{I} .48^{\prime} 309747-\mathrm{dc2} 3$

2011027971

Manufactured in the United States of America

$\begin{array}{llllllllll}20 & \text { I9 } & \text { I8 } & \text { I7 } & \text { I6 } & \text { I5 } & \text { I4 } & \text { I3 } & \text { I2 } \\ \text { I0 } & 9 & 8 & 7 & 6 & 5 & 4 & 3 & 2 & \text { I }\end{array}$

In keeping with its commitment to support environmentally responsible and sustainable printing practices, UC Press has printed this book on Cascades Enviro Ioo, a ı००\% post consumer waste, recycled, de-inked fiber. FSC recycled certified and processed chlorine free. It is acid free, Ecologo certified, and manufactured by BioGas energy. 
For my father and grandfather,

who started me along this river so many years ago 
This page intentionally left blank 